\title{
FINITE MARKOV CHAIN MODEL IN LITHOFACIES ANALYSIS: AN EXAMPLE FROM THE BIDA SANDSTONE, BIDA BASIN, NIGERIA
}

\author{
A. U. OKORO AND H. N. EZEH
}

(Received 16, October 2008; Revision Accepted 16, December 2009)

\begin{abstract}
The Markov Chain Stochastic Process has been used both to analyze the vertical lithofacies of the Bida Sandstone (Campanian - Maastrichtian) in Bida area and interprete the corresponding depositional systems. Six lithofacies, comprising of F1: conglomerates (breccias); F2 : medium - very coarse, pebbly sandstone with dominant trough beddings ; F3: coarse-grained pebbly sandstone with small scale trough or planar cross-beds; F4: mediumgrained planar cross- bedded or massive sandstone lithofacies with abundant scattered pebbles ; F5: very fine to fine -grained, planar cross-bedded or parallel laminated sandstones; and F6: siltstone and claystone, variegated and mottled in places - ripple/parallel laminations and rootlets were recognised. A high frequency fining-upward (FU) transition pattern (or cycles) with a "memory function" was distilled from the sequence using the Markov Chain Stochastic Process. The fining- upward (FU) motif is interpreted as a product of braided river depositional system with well- developed flood plains and lakes behind non-cohesive river banks. The cycles indicate channel migration within a broad topographically variable alluvial plain, fed by basin-margin fans.
\end{abstract}

\section{INTRODUCTION}

Sedimentary environments generate characteristic lithofacies defined by variables such as texture, sedimentary structures, sand body geometry, and fossil contents. Traditionally, sedimentary environments and models are reconstructed based on visual description of these variables which are subjective. The interpretations and environmental models derived from such generally subjective data are therefore wanting. New tools in stratigraphy including semi-quantitative and quantitative techniques for data analysis were introduced to compliment descriptive stratigraphic analysis (Bokman, 1953; Schwarzacher, 1953; Krumbein and Dacey, 1969; Dacey and Krumbein, 1970; Selley, 1969; Hattori, 1973; Miall, 1973; Bernajee, 1979; Hoque and Nwajide, 1985; Gradstein, 2005; Perlmutter and Deazambuja Filho, 2005). These techniques, such as the finite markov chain analysis, time series analysis, power spectral density analysis and Kolmogorov functions introduce some objectivity and precision in analyzing "trends" and interpreting stratigraphic models and environments. They also provide multiple working hypotheses to detect and define sequence stratigraphic trends in analysed sequences. Since the 1980s, research in quantitative stratigraphy and particularly the Markov Chain Stochastic Process has waned.

The purpose of this paper is two - fold. First, it is to rekindle interest in quantitative stratigraphy, particularly the Markov Chain Stochastic Process, by examining vertical lithofacies patterns using the lithofacies versus order interaction (Selley, 1969, Miall, 1973, Bernajee, 1979); and secondly, to interprete the depositional environment of the rocks using the Markov model. The Markov Chain Stochastic Process has been applied in analyzing the sedimentary facies exposed in the Bida Sandstone in the Bida Basin, Nigeria. The stratigraphic data used in this analysis were obtained through careful and detailed logging of exposed sections, comprising of conglomerates (breccias), sandstones and mudrocks in Bida, Badegi, Agaie, Lemu and Kutriko areas of the Bida Basin (Fig. 1).

A. U. Okoro, Department of Geology and Exploration Geophysics, Ebonyi State Univesity, P.M.B. 053, Abakaliki, Nigeria

H. N. Ezeh, Department of Geology and Exploration Geophysics, Ebonyi State Univesity, P.M.B. 053, Abakaliki, Nigeria 


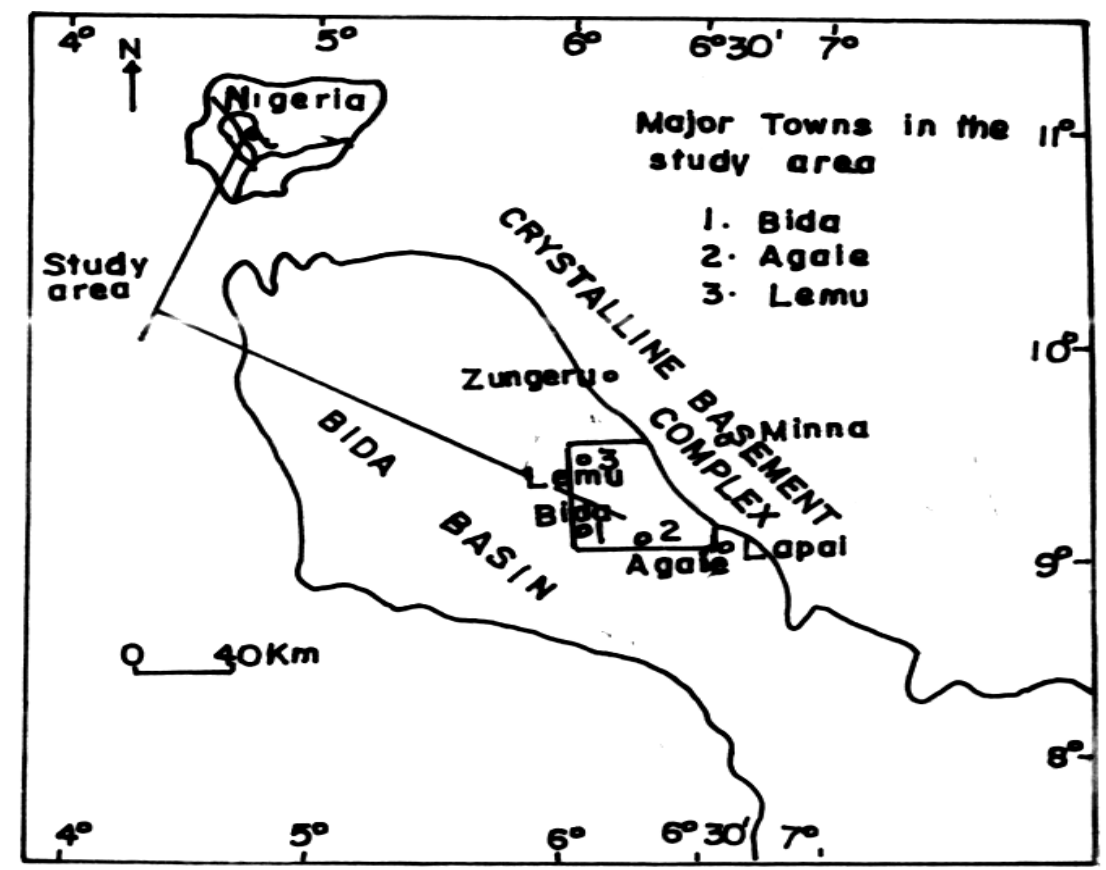

\section{FIG.1: LOCATION MAP OF BIDA BASIN SHOWING THE STUDY AREA}

\section{PHILOSOPHY AND METHODOLOGY}

The Markov Chain Process is stochastic: that in which an event is probabilistically dependent on the preceding event. It uses a lithology versus order relationship to structure a Markov model for stratigraphic analysis. In the first order Markov event, a lithofacies state, $F_{j}$ observed at point $n$, depends on the lithofacies state, $F_{i}$ observed at point $(n-1)$. The transition probability of a lithofacies state, $F_{j}$ observed at point $n$, given that the lithofacies state is now in state $F_{i}$, at point $(n-1)$ is denoted by $\mathrm{Pij}(\{\mathrm{n}-1\}, \mathrm{n})=\mathrm{P}\left(\mathrm{F}^{\mathrm{n}} / \mathrm{Fi}^{\mathrm{n}-1}\right)$ (Selley, 1969). The Markov model therefore, assumes that a lithofacies state is influenced by that of the underlying lithofacies. This historical link between the events is called a "memory function" (Selley, 1969; Krumbein and Dacey, 1969). Selley (1969) described three models of structuring lithofacies states observed in the field for finite Markov analysis. These are: 1) the regular Markov Matrix where stratigraphic intervals are sampled at fixed or regular vertical intervals of equal thickness. This method gives an accurate measure of the relative frequencies of the lithofacies types in the sections but does not emphasize changes in the depositional environment; 2) the embedded Markov Matrix which emphasizes every lithological change and is a good method for understanding the evolution of depositional environments and processes; and 3 ) the multistory Markov Matrix which is a variant of the embedded Markov Matrix in which lithofacies change is important but multistory lithologies (where similar lithofacies but with different texture or sedimentary structures) are also counted. The multistory Markov Chain process is applied in this study. Every lithofacies change is counted as at when it occurs in the stratigraphic setting. A lithologic state can pass upwards into a similar lithology but of different grainsize or sedimentary structure. The transition count matrix (TCM) will be such that along the principal diagonal of the erected matrix, the values will be zero (ie $F_{i j}=0$ ).

\section{GEOLOGICAL SETTING}

The Bida Basin is a NW - SE trending elongate intracratonic depression lying on the northwestern continuation of the Anambra Basin. The basin is shallow and filled with unfolded and undeformed CampanoMaastrichtian sediments (Adeleye, 1976; Jan Du Chene et al., 1978). The basin generally dips gently southeast and is bounded by gravity faults (Likkason and Ojo, 1999). The origin of the basin has been a subject of some controversy. A generally held opinion is that the basin originated as a simple intracratonic sag (Adeleye, 1976; Ojo and Ajakaiye, 1976 and Wright et al., 1985). Kogbe et al., (1981) and Likkason and Ojo, (1999) proposed a rift origin for the basin while Braide (1992) suggested a wrench fault tectonic model similar to that which generated the Benue Trough for the genesis of the basin.

\section{STRATIGRAPHY}

The stratigraphic relationship of the basin was given by Adeleye and Dessauvagie (1972) and Adeleye (1976) based on studies of sediments near Bida. They recognized the Bida Sandstone as the basal unit lying unconformably on the Precambrian Basement Complex, and successively overlain by the Sakpe Ironstone, the Enagi Siltstone and the Battati Ironstone Formations. Ten sections of the Bida Sandstone were logged in Bida, Badegi, Agaie, Lemu and Kutriko areas (Fig. 1) 
from which six lithofacies were recognised. Each lithofacies was characterized based on its gross lithology, texture, sedimentary structures and nature of discontinuity surfaces. Figs $2 a-d$ are logged sections showing the following different lithofacies:

F1- Conglomerate (braccia) lithofacies with basal erosion discontinuity surface.

F2 - Medium - very coarse, pebbly sandstone with abundant trough cross-beddings.

F3 - Coarse-grained, pebbly sandstone with small scale trough or planar cross- beds.
F4 - Medium- grained, planar cross- bedded or massive sandstone lithofacies with abundant scattered pebbles.

F5 - Very fine- to fine- grained, planar cross- bedded or parallel laminated sandstones.

F6 - Siltstone and claystone; variegated and mottled; ripple or parallel laminated in places and with rootlets.

These lithofacies were structured into a multistory Markov Model in the form of a tally matrix to indicate the observed cumulative number of times which a particular lithofacies state overlies another.

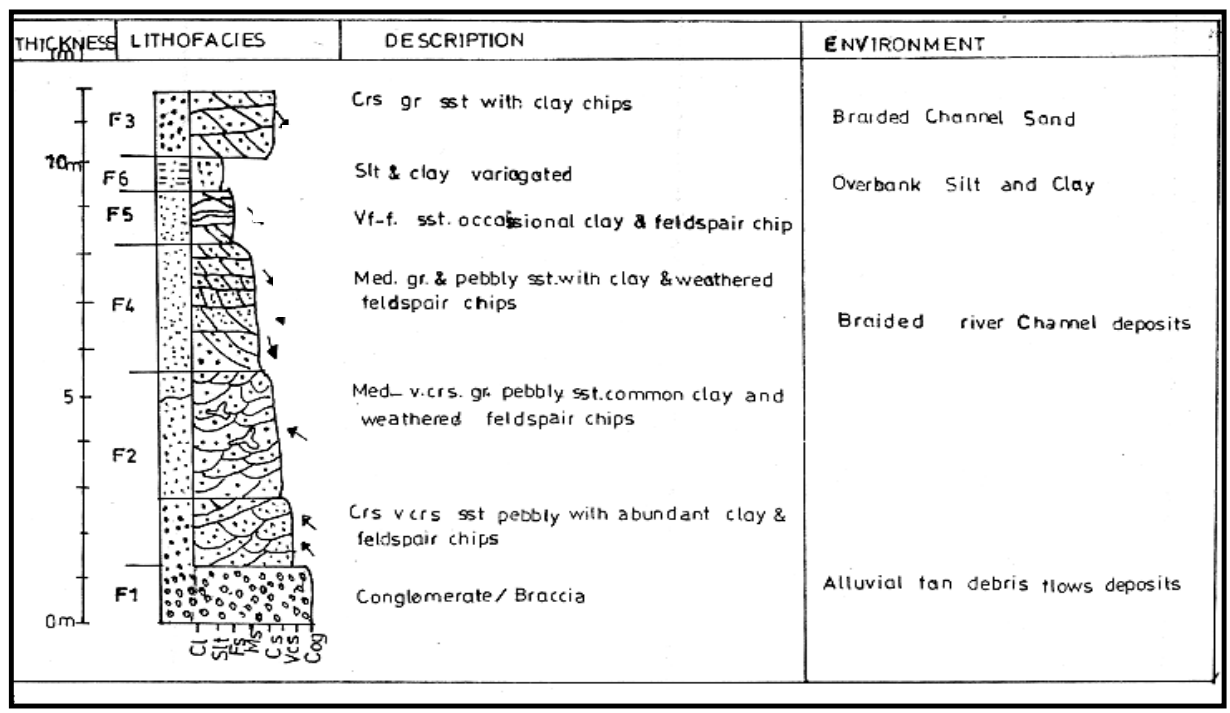

Fig. 2 a: Lithofacies F1 - F6 in outcrop section of the Bida Sandstone at the Bida Cemetery behind the Government Girls' Secondary School, Bida

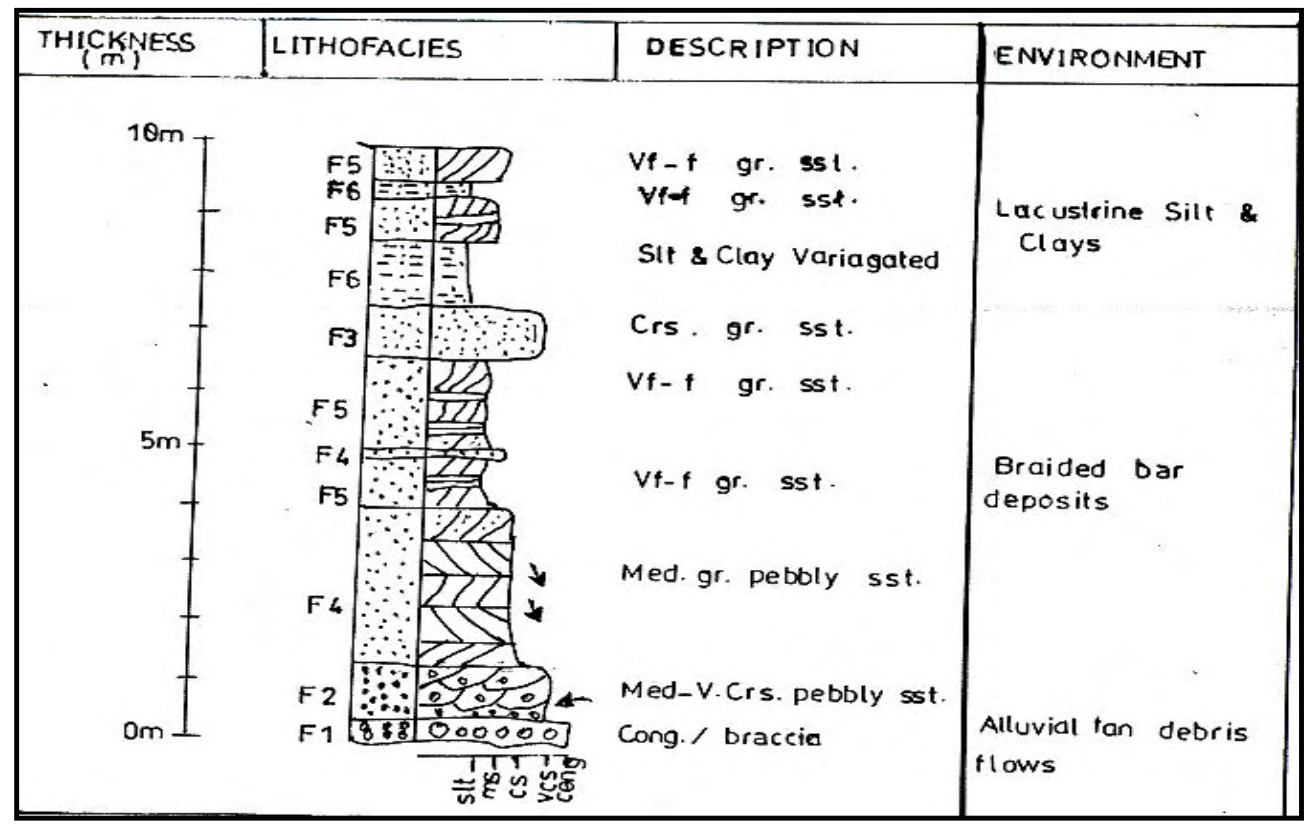

Fig. 2b: The lithofacies section of the Bida Sandstone on a small peak north of Agaie town 




Fig. 2c: The lithofacies section of Bida Sandstone at the Bida Water Reservoir

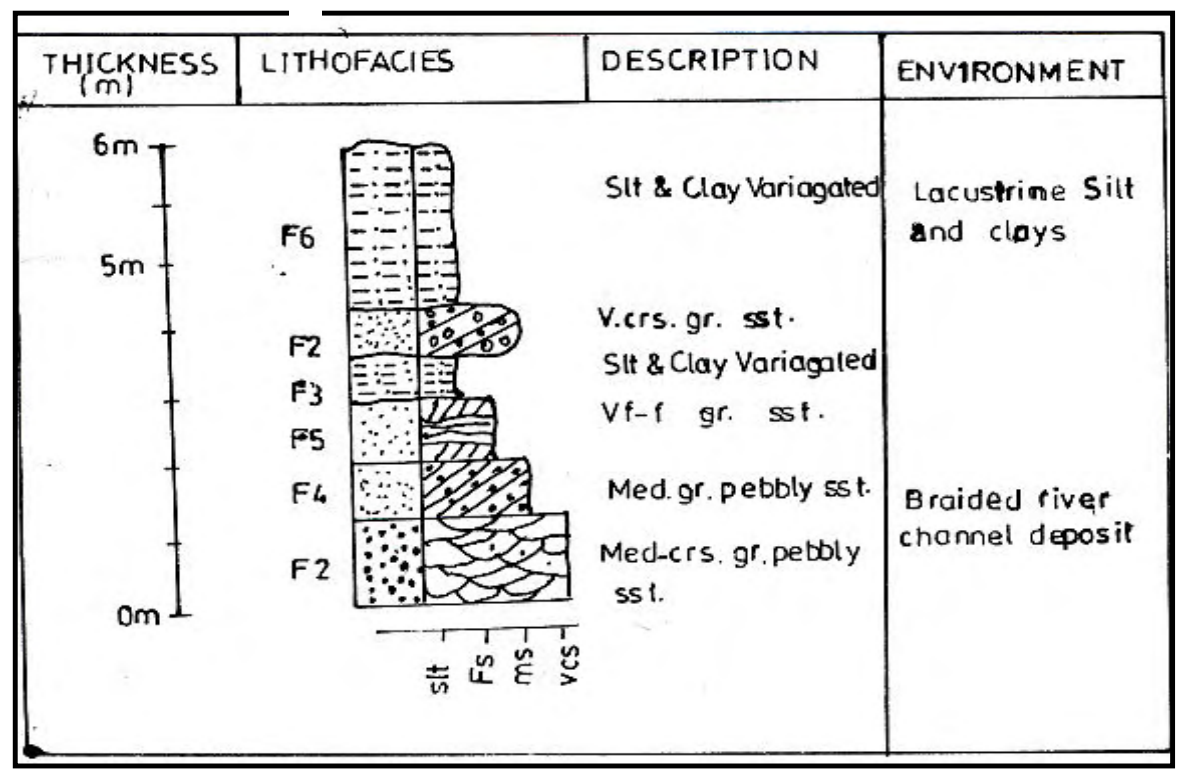

Fig. 2d: The Lithofacies section on a Mesa north of Essa village

Table 1a shows the Transition Count Matrix (TCM) for the lithofacies observed in the study area. An Independent Transition Matrix (ITM) was computed from the TCM using the formula:

ITM $=\left(C_{t} \times R_{t}\right) / T$

Where $C_{t}=$ Column total

$\mathrm{R}_{\mathrm{t}}=$ Row total and

$\mathrm{T}=$ Total number of transitions

In the Independent Transition Matrix, (ITM), the frequency with which each lithofacies underlies another is proportional to its relative abundance, although no lithofacies transition pattern is obvious. Table $1 \mathrm{~b}$ shows the Independent Transition Matrix (ITM) for the structured lithofacies. However, when the Difference Matrix (DM) is calculated, lithofacies transition patterns and their frequencies become visible. The Difference Matrix (DM) is calculated as TCM - ITM for each corresponding cell. Table 1c is the Difference Matrix (DM) computed from the structured TCM and ITM for the logged sections in Bida area. The positive values in the Difference Matrix (DM) illustrate the Markovian property and reflect the transitions that have greater than random frequencies. To visualize the transition patterns, a Facies Relationship Diagram (FRD) is constructed to represent lithofacies path lines using the positive entries in the Difference Matrix (DM) (Miall, 1973). 
Table 1a: Transition Count Matrix (TCM) showing the number of times one lithofacies overlies another in the sequences logged (observed transition matrix).

OVERLYING LITHOFACIES

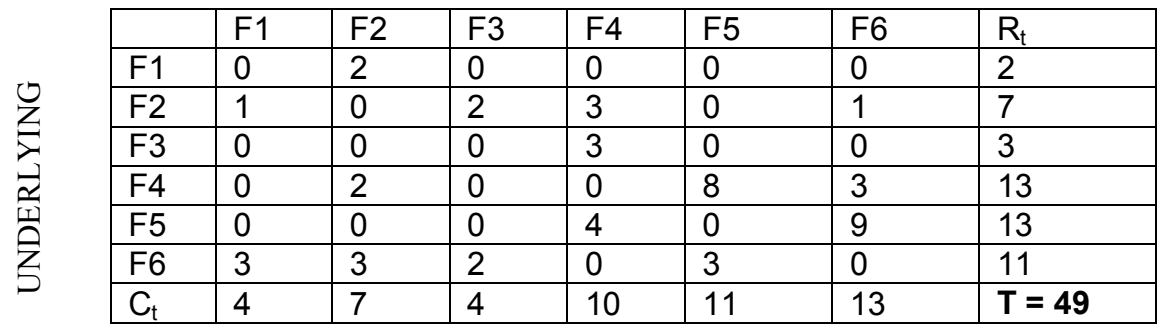

$\mathrm{C}_{\mathrm{t}}=$ Column total. $\mathrm{R}_{\mathrm{t}}=$ Row total. $\mathrm{T}=$ Total number of transitions

Table 1b: Independent Trial Matrix (ITM) computed from (TCM).

OVERLYING

\begin{tabular}{|c|c|c|c|c|c|c|}
\hline & $\mathrm{F} 1$ & F2 & F3 & $\mathrm{F} 4$ & $\mathrm{~F} 5$ & F6 \\
\hline F1 & 0.16 & 0.29 & 0.16 & 0.41 & 0.45 & 0.53 \\
\hline F2 & 0.57 & 1.00 & 0.57 & 1.43 & 1.57 & 1.86 \\
\hline F3 & 0.24 & 0.42 & 0.24 & 0.61 & 0.67 & 0.80 \\
\hline $\mathrm{F} 4$ & 1.06 & 1.86 & 1.06 & 2.65 & 2.92 & 3.45 \\
\hline F5 & 1.06 & 1.86 & 1.06 & 2.65 & 2.95 & 3.45 \\
\hline F6 & 0.90 & 1.57 & 0.90 & 2.24 & 2.47 & 2.92 \\
\hline
\end{tabular}

Table 1c: Difference Matrix (TCM - ITM) showing lithofacies transition patterns and frequencies OVERLYING

\begin{tabular}{|c|c|c|c|c|c|c|}
\hline & $\mathrm{F} 1$ & F2 & F3 & F4 & F5 & F6 \\
\hline F1 & -0.16 & 1.71 & -0.16 & -0.41 & -0.45 & -0.53 \\
\hline F2 & 0.43 & -1.0 & 1.43 & 1.57 & -1.57 & -0.86 \\
\hline F3 & -0.24 & -0.42 & -0.24 & 2.39 & -0.67 & -0.80 \\
\hline $\mathrm{F} 4$ & -1.06 & 0.14 & -1.06 & -2.65 & 6.08 & -0.45 \\
\hline F5 & -1.06 & -1.86 & -1.06 & 1.35 & -2.95 & 5.55 \\
\hline F6 & 2.10 & 1.43 & 1.10 & -2.24 & 0.53 & -2.92 \\
\hline
\end{tabular}

Fig.3 is the Facies Relationship Diagram (FRD) for the analyzed Bida Sandstone facies showing one finingupward transition path line_(a fining-upward sequence from conglomerate a the base to clay at the top).

$\mathrm{F} 1 \rightarrow \mathrm{F} 2 \rightarrow \mathrm{F} 3 \rightarrow \mathrm{F} 4 \rightarrow \mathrm{F}^{2} \rightarrow \mathrm{F} 6$.

To determine if this transition pattern is a product of chance events (ie random) or if the sedimentation process had a "memory function" (ie Markovian), a test of significance was applied to the result.

The Chi Square $\left(x^{2}\right)$ Test has been used by several authors for this purpose (Miall, 1973; Bernajee, 1979). In this test, a null hypothesis, $\mathrm{H}_{\mathrm{o}}$, is proposed which assumes that the transition pattern generated by the sedimentary process was random ie non Markovian. The $x^{2}$ test is used to reject or uphold this hypothesis.

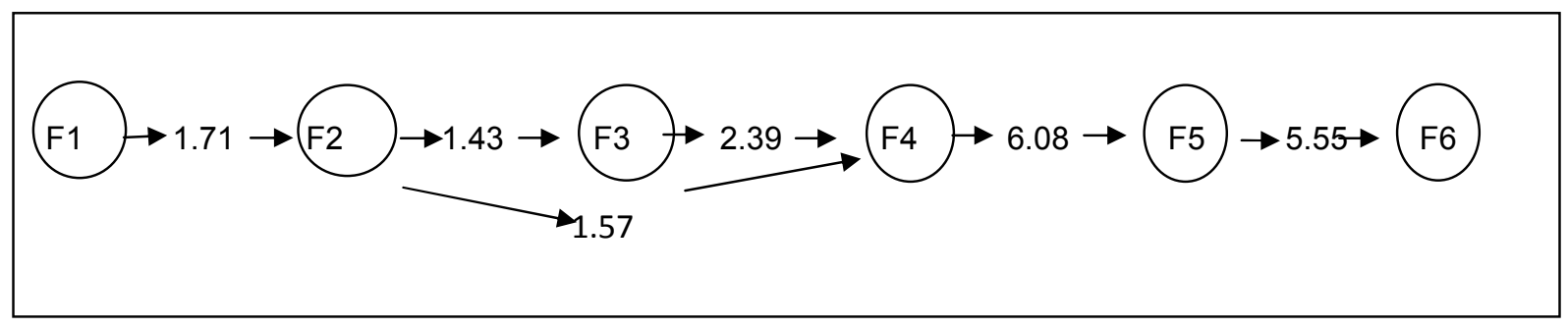

Fig. 3: Facies Relationship Diagram (FRD) for the analyzed Bida Sandstone facies showing a fining-upward (F - U) transition path lines from Lithofacies F1 - Lithofacies F6

From the Independence Transition Matrix (ITM) and the Difference Matrix (DM) (Tables $1 \mathrm{~b}$ and 1c),

$\mathrm{X}^{2}=\sum(\mathrm{DM})^{2} /(\mathrm{ITM})$

where DM = TCM - ITM;

$\mathrm{TCM}=$ Transition Count Matrix and
ITM = Independent Trial Matrix.

Table 2 is the result of the computed $X^{2}$ value $\{\Sigma$ $\left.(\mathrm{DM})^{2} /(\mathrm{ITM})\right\}$ from the lithofacies transition patterns of the Bida Sandstone showing Chi Square $\left(X^{2}\right)=78.97$. 
The number of degrees of freedom (DF) is given as the square of the difference between the number of facies with non-zero entries in the Independent Count Matrix minus one ie

$\mathrm{DF}=(\mathrm{N}-1)^{2}=(6-1)^{2}=25^{0}$.

Where $N=$ number of lithofacies in ITM (Table 1b) with non-zero entries.
In the standard Chi-Square Table, at a limiting value at $95 \%$ confidence level, (ie $X^{2} 0.95$ at $25^{\circ}$ of freedom), $x^{2}=37.65$.

This is less than the $x^{2}$ value of 78.97 computed from the Difference Matrix (DM) and Independent Transition Matrix (ITM) from the natural lithofacies transitions.

Table 2: Result of the Chi- Square $\left(X^{2}\right)$ test computed as $\mathrm{DM}^{2} / \mathrm{ITM}$

\begin{tabular}{|l|l|l|l|l|l|l|l|}
\hline & F1 & F2 & F3 & F4 & F5 & F6 & TOTAL \\
\hline F1 & 0.16 & 10.08 & 0.16 & 0.41 & 0.45 & 0.53 & $\mathbf{1 1 . 7 9}$ \\
\hline F2 & 0.32 & 1.00 & 3.59 & 1.72 & 1.57 & 0.40 & $\mathbf{8 . 6 0}$ \\
\hline F3 & 0.24 & 0.42 & 0.24 & 9.36 & 0.67 & 0.80 & $\mathbf{1 1 . 7 3}$ \\
\hline F4 & 1.06 & 0.01 & 1.06 & 2.65 & 12.65 & 0.06 & $\mathbf{1 7 . 4 9}$ \\
\hline F5 & 1.06 & 1.86 & 1.06 & 0.69 & 2.95 & 8.93 & $\mathbf{1 6 . 5 5}$ \\
\hline F6 & 4.90 & 1.30 & 1.34 & 2.24 & 0.11 & 2.92 & $\mathbf{1 2 . 8 1}$ \\
\hline \multicolumn{7}{|l|}{} \\
DM
\end{tabular}

If the computed $x^{2}$ value (ie $\left\{\Sigma(D M)^{2} /(\right.$ ITM) $\}$ is higher than the limiting $x^{2}$ value at $95 \%$ confidence interval from the Chi Square Table, then the null hypothesis $\left(\mathrm{H}_{0}\right)$ is rejected (i.e. sedimentary process is Markovian and not random) (Miall, 1973; Banerjee, 1979; Selley, 1969). If on the other hand $\left\{\Sigma(\mathrm{DM})^{2} /(\right.$ ITM $\left.)\right\}$ is lower than the limiting $x^{2}$ at $95 \%$ confidence interval, then the null hypothesis is accepted (ie sedimentary process is non-Markovian and random)

In this study the computed $x^{2}$ from the Difference and Independent Trial Matrices at $25^{\circ}$ of Freedom, $\left(\sum(\mathrm{DM})^{2} /(\mathrm{ITM})=78.97\right)$ is higher than $x^{2}$ value at $95 \%$ confidence limit and at $25^{\circ}$ of Freedom from the Chi Square Table given as 37.65. The null, $\left(H_{\circ}\right)$ is rejected; therefore the lithofacies transition pattern Markovian, with "memory function."

\section{DISCUSSION}

A Markovian process is detected in a succession when the underlying lithofacies has an influence on the contents of the overlying unit. Furthermore, the transition path lines obtained provide a strong basis for interpreting the depositional environments. Banerjee (1979) however, cautioned that the detection of cycles in a Markovian stochastic process is not sufficient for the interpretation of depositional models. A concrete meaning must be given to the nature of the cycles which should be complimented with other sedimentological variables such as texture and sedimentary structures to interprete depositional environments. The fining-upward (FU) depositional cycles as indicated by the Facies Relationship Diagram (FRD) could be characteristic of fluvial, meandering river depositional systems (Allen, 1970; Walker, 1984). They could also represent active bar sequences in braided river channels (Miall, 1978; Cant, 1982) or sheet flood deposits of decelerating river flows in the flood plains of rivers (Cotter, 1978; Cant, 1982). Olugbemiro and Nwajide (1990) interpreted these sediments as products of high-sinuosity channels based on unimodal paleocurrents and predominance of lower flow regime structures such as the planar cross-beds.. However, the fining-upward transition pattern shown by the FRD, the dominantly very coarse-grained and pebbly nature of the deposits with its abundant vein quartz, weathered feldspar and clay chips suggest deposition of active braid bars of an alluvial braided river system (Miall, 1978; Braide, 1992d).

The fining-upward cycles indicate migration of channel locations within broad topographically variable plains fed by basin-margin alluvial fans. Based on the very coarse - to medium- grained sizes coupled with the presence of quartz pebbles, and weathered feldspar and clay chips, the cycles are interpreted as alluvial fan to braided river depositional systems (Miall, 1978, Selley, 1988; Braide, 1992d). The high frequency of the siltstone and clay units (F6 lithofacies) suggests the presence of lakes and well-developed and vegetated river flood plains behind the non-cohesive river banks. It is also a manifestation of the higher preservation potential of fine-grained and overbank sediments over the river channel facies.

\section{CONCLUSION}

Finite Markov Chain stochastic process has been used to objectively distill the actual lithofacies transition trend which was masked by several erosion truncation surfaces in the Bida Sandstone. A finingupward (FU) transition pattern is documented in the logged sections. The transition pattern was also found to be Markovian, indicating historical links between the underlying and overlying lithofacies, and consequently, the environments of deposition. The high frequency fining-upward (FU) cycle shown by the logged sections indicates deposition in alluvial fan and braided river systems. Finite Markov Chain Stochastic Process has been shown in this study to be an appropriate quantitative method for defining lithofacies trends with precision. It is suggested, therefore, that this method be applied in oil well lithofacies data analysis, to determine and define lithofacies trends or cycles. When such cycles are established in a well, they can be used for local and field-wide correlation. They would also be useful to predict stratigraphy in unexplored geologically contiguous areas in a basin.

\section{REFERENCES}

Adeleye, D.R., 1973. Origin of ironstones: an example from the middle Niger valley, Nigeria Journal of Sedimentary Petrology, 43, p.709 -727. 
Adeleye, D.R., 1976. Geology of the middle Niger valley, in Kogbe, C.A(ed); Geology of Nigeria. Elizabethan Press, Nigeria, p......

Adeleye, D.R. and Dessauvagie, T.F.J., 1972. Stratigraphy of the Niger Embayment near Bida, Nigeria, in Dessauvagie, T.F..J. and Whiteman, A.J (eds.) University of Ibadan Press, p.181 186.

Allen, J. R. L., 1970. Studies in fluviatile sedimentation: a comparison of fining upwards cyclothems with special reference to coarse member composition and interpretation. Jour. Sed. Pet., 40 , p.298 - 325 .

Banerjee, I., 1979. Quantitative analysis of stratigraphic sequences. Jour. Min. and Geol., 16, (2): p.111- 118.

Bokman, J., 1953. Lithology and Petrology of the Stanleys and Jackfork Formations. Jour. Geology, 61: p.152 - 170.

Braide, S. P., 1992c. Syntectonic fluvial sedimentation in the central Bida Basin. Jour. Min and Geol., 28 , p. $55-64$.

Braide, S.P. 1992d. Alluvial fan depositional model in the northern Bida Basin. Jour. Min and Geol., 28, (1): p. $65-75$.

Cant, D.J., 1982. Fluvial facies models and their applications .In P.A. Scholle and D.R. Spearing (eds.) Sandstone depositional Environments, AAPG Publ., p.115- 137.

Cant, D.J and Walker, R. G., 1978. Fluvial processes and facies sequences in sandy braided Saskatchewan River, Canada. Sedimentology, 25: p.625 - 648.

Cotter, E., 1978. The evolution of fluvial styles with special reference to the central Appalachian Paleozoic. In A.D. Miall (ed.) Fluvial Sedimentology. Canadian Soc. Pet. Geol. Memoir 5, Calgary, Alta. P.361 - 383.

Dacey, M.F and Krumbein, W.C., 1970. Markovian models in stratigraphic analysis. Jour. Int. Assoc. Math. Geol., 2, p. $175-181$.

Gradstein, F . M., 2005. Quantitative methods for applied microfossil biostratigraphy. In Koutsoukos, E. A. M. (ed); Applied Stratigraphy. Springer, Netherlands. p. $359-$ 386.

Hattori, I., 1973. Mathematical analysis to discriminate two types of sandstone-shale alternations. Sedimentology, 20, p. $331-345$.

Hoque, $M$ and Nwajide, C.S., 1985. Application of Markov chain and entropy analysis to lithologic successions: an example from the Cretaceous of the Benue Trough (Nigeria). Geol. Rndsh. V. 74 , p. $165-177$.

Jan Du Chene, R.E., Adgoke, O.S. Adeniran, S.A and Petters, S.W, 1978. Palynologyand foraminifera of the Lokoja Sandstone (Maastrichtian), Bida Basin, Nigeria. Revista Espanolo di Micropaleontogia, 10, p.379-393.

Kogbe, C.A. Ajakaiye, D.E and Matheis, G., 1981. Confirmation of a rift structure along the midNiger valley, Nigeria. Journal of African Earth Sciences, I, p. 127-131.

Krumbein, W. C and Dacey, M. F., 1969. Markov chains and embedded chains in geology. Jour. Int. Assoc Math. Geol., 1, p.79 -96.

Likkason, O.K and Ojo, S.B, 1999. Additional evidence from gravity for a basic intrusion in the Middle Niger Basin, Nigeria. Journal of Mining \& Geology,.35, (2): p.171-181.

Miall, A. D., 1973. Markov Chain analysis applied to an ancient alluvial plain succession. Sedimentology, 20, p. $347-361$.

Miall, A.D., 1978. Lithofacies types and vertical profiles models in braided rivers: a summary. Canadian Soc. Pet. Geol. Memoir 5, p. 597 - 604.

Ojo S. B and Ajakaiye, D. E., 1976 Preliminary interpretation of gravity measurements in middle Niger Basin, Nigeria. in Kogbe, C. A (ed). Geology of Nigeria, Elizabethan Publ., Co. Lagos. p.295 - 307

Olugbemiro, R. O.and Nwajide, C. S., 1990. An analysis of lithologic successions in the Bida Basin. Abstract vol., $26^{\text {th }}$ Annual Conf. of NMGS, Kaduna, 1990, p. 25.

Perlmutter, M. A and Deazambuja Filho, N. C., 2005. Cyclostratigraphy. In Koutsoukos, E. A. M. (ed) Applied Stratigraphy, Springer, Netherlands. p. $301-338$.

Pettijohn, F.J., Potter, P. E and Siever, R., 1972. Sand and sandstone. Springer Publ., Berlin Heidelberg - New York. 618p.

Schwarzacher, W., 1953. Cross-bedding and grain size in the Lower Cretaceous sands of East Anglia. Geol. Magazine, 90, p. 3322 -3330.

Selley, R. C., 1969. Markov chain analysis. Jour. Geol. Soc. Lond., 125, p.551 - 581.

Selley, R. C., 1988. Applied Sedimentology. Academic Press, London. 446p.

Walker, R. G., 1984. Sandy fluvial Systems. In R. C. Walker (ed.) Facies Models and Environmental Analysis. $3^{\text {rd }}$ Ed., Geoscience Canada, p.71- 90

Wright, J. B., Hastings, D. A. Jones, W. B. and Williams, H. R., 1985. Geology and Mineral Resources of West Africa. George Allen and Unwin, London, 187p. 